\title{
Crafting Care That Fits: Workload and Capacity Assessments Complementing Decision Aids in Implementing Shared Decision Making
}

Thomas H Wieringa ${ }^{1}$, BSc, MSc, PhD; Manuel F Sanchez-Herrera ${ }^{2}$, MD; Nataly R Espinoza ${ }^{2}$, MSc, MD; Viet-Thi $\mathrm{Tran}^{3}, \mathrm{MSc}, \mathrm{MD}, \mathrm{PhD}$; Kasey Boehmer ${ }^{2}, \mathrm{MPH}, \mathrm{PhD}$

\footnotetext{
${ }^{1}$ Department of Medical Psychology, Amsterdam UMC, Amsterdam, Netherlands

${ }^{2}$ Knowledge and Evaluation Research Unit, Mayo Clinic, Rochester, MN, United States

${ }^{3}$ METHODS Team, Centre of Research in Epidemiology and StatisticS, Université de Paris, Institut National de la Santé et de la Recherche Médicale, Paris, France
}

\section{Corresponding Author:}

Thomas H Wieringa, BSc, MSc, PhD

Department of Medical Psychology

Amsterdam UMC

van der Boechorststraat 7

Amsterdam, 1081BT

Netherlands

Phone: 31204448352

Email: t.wieringa@amsterdamumc.nl

\begin{abstract}
About $42 \%$ of adults have one or more chronic conditions and $23 \%$ have multiple chronic conditions. The coordination and integration of services for the management of patients living with multimorbidity is important for care to be efficient, safe, and less burdensome. Minimally disruptive medicine may optimize this coordination and integration. It is a patient-centered approach to care that focuses on achieving patient goals for life and health by seeking care strategies that fit a patient's context and are minimally disruptive and maximally supportive. The cumulative complexity model practically orients minimally disruptive medicine-based care. In this model, the patient workload-capacity imbalance is the central mechanism driving patient complexity. These elements should be accounted for when making decisions for patients with chronic conditions. Therefore, in addition to decision aids, which may guide shared decision making, we propose to discuss and clarify a potential workload-capacity imbalance.
\end{abstract}

(J Participat Med 2020;12(1):e13763) doi: 10.2196/13763

\section{KEYWORDS}

decision making; decision support techniques; patient-centered care

\section{Minimally Disruptive Medicine}

About $42 \%$ of adults have one or more chronic conditions and $23 \%$ have multiple chronic conditions (ie, multimorbidity) [1,2]. The coordination and integration of services for the management of patients living with multimorbidity is important for care to be efficient, safe, and less of a burden [2,3]; however, these services are often found to be suboptimal in clinical practice [4,5], which may lead to polypharmacy, increased treatment costs, side-effects, and unintended drug interactions [5]. In the end, this may overwhelm patients (eg, in what they have to do to control their disease) and in turn result in poor adherence, wasted resources, and poor outcomes [5-9].
Minimally disruptive medicine may optimize the coordination and integration of services [4]. It is a patient-centered approach to care focusing on achieving patient goals for life and health [5] by seeking care strategies that fit patient context [4]. The cumulative complexity model practically orients minimally disruptive medicine-based care [1]. In this model, the patient workload-capacity imbalance is the central mechanism driving patient complexity. Workload ("What patients have to do") encompasses the demands on patients' time and energy, including not only the demands of treatment and self-care, but also the demands of life in general. Capacity ("What patients can do") concerns patients' abilities and resources to handle health care and life work (eg, functional morbidity, financial/social resources, literacy). Workload-capacity 
imbalance can lead to problems accessing and using care, as well as enacting self-care [1]. Ultimately, this can result in poor adherence and poor patient outcomes [8-10].

All care strategies influence workload and capacity by affecting (positively or negatively) treatment and illness burden, respectively. For example, intensifying a patient's treatment may reduce his symptoms and illness burden at the cost of an increased treatment burden [1]. Awareness of a patient's capacity and workload is therefore critical in deciding on a patient's care strategy. Indeed, inattention to contextual information may lead to errors in this choice [11].

\section{Shared Decision Making}

When aiming for treatment decisions that result in desirable outcomes for the patient, active participation and engagement of both the clinician and patient is needed [12]. Shared decision making $[13,14]$ is a patient-centered approach in which clinicians and patients work together to choose the best course of action for each patient's particular situation [15]. Although shared decision making often does not impact clinical outcomes [16-18], it tends to result in improved affective and cognitive outcomes [16] and can also help facilitate a stronger clinician-patient relationship and a shared understanding of treatment for patients' health and life goals $[19,20]$. Some ethical and clinical arguments also advocate for shared decision making [16,21-29], but despite this, it is not yet routine in clinical practice [30,31]. Multiple reasons are present for the suboptimal implementation of shared decision making, such as a perception-reality gap in which clinicians feel they are practicing shared decision making [31].

Shared decision making was first proposed in 1982 [32]. One of its first models was proposed by Charles et al [33,34], which later models built upon $[33,34]$. Since then, multiple definitions and models of shared decision making have been developed [35-39]. In this commentary, six key elements of quality shared decision making are defined [40,41].

- Situation diagnosis (understanding the patient's situation and establishing what aspects require action)

- Choice awareness (indicating that more than one option is available and that the patient's preferences are important in deciding on the course of action)

- Option clarification (describing the options available)

- Discussion of pros and cons (explaining the pros and cons of the available options)

- Deliberation of patient preferences (discussing the patient's preferences)

- $\quad$ Making the decision $[40,41]$

Some shared decision making models also include patient value elicitation as a key element [42,43]. We assume that value elicitation is implicitly handled in deliberation of patient preferences, as we expect that a patient's preferences also reflect the patient's important values. Furthermore, the order that elements are handled within the encounter is not fixed or important as long as all elements are included. In our opinion, the natural flow of the conversation is superior to the order of the key elements or the handling of value elicitation implicitly or explicitly. Namely, the clinician and patient should work together in partnership [4,15], instead of checking the elements' boxes in a mechanical way.

\section{Shared Decision Making Decision Aids}

Decision aids are designed to help patients participate in decisions that involve weighing the pros and cons of different treatment options and can help patients choose an option that is congruent with their values [44]. Decision aids are designed to supplement rather than replace clinician-patient interactions [42].

The International Patient Decision Aid Standards Collaboration developed a minimum set of standards for qualifying a tool as a decision aid, which states that all shared decision making key elements, except making the decision, should be incorporated in the tool to regard it as a decision aid [45]. Despite this, most decision aids developed for chronic illnesses are focused on communicating options and their pros and cons [41]. The situation diagnosis is less often included in decision aids for persons with chronic conditions [41], while understanding the patient's context is a prerequisite for care to fit the patient's context. Moreover, clinicians probe for contextual information less often than for biomedical information [11] and thus may neglect this information when making decisions with patients.

\section{Workload and Capacity Assessments}

To address the problem of neglecting contextual information, we propose to systematically supplement the use of decision aids for shared decision making with workload and capacity assessments [4]. Workload assessments aim at identifying the intrusiveness of health on life and to find opportunities for treatment plan augmentation. Capacity assessments aim at identifying contextual limitations in patients' capacity that may impact care effectiveness and that may be amenable to support or intervention [4].

The Instrument for Patient Capacity Assessment (ICAN) discussion aid is a tool that can be helpful in carrying out capacity and workload assessments [46,49]. ICAN is a paper-based tool that the patient can fill out while waiting for the clinician. It asks which areas of the patient's life (eg, family and friends, work, living situation) are sources of satisfaction, burden, or both. The patient is also asked whether things they have been asked to do to care for their health are a help, a burden, or both. Common self-management activities are listed (eg, taking medications and self-monitoring), and blank spaces are provided for any self-management tasks not listed. During the conversation the clinician is asked to review the three questions on the back of the aid: 1) "What are you doing to manage your stress?" (brings forth typical day-to-day and competing priorities), 2) "Where do you find the most joy in your life?" (to assess if the patient is struggling with biographical disruption from their treatment and illness), and 3) "What else is on your mind today?" (focuses on the visit today) $[46,49]$. Biographical disruption can be described as "an assault of chronic illness on often cherished conceptions of self, identity and life course, resulting in a fundamental rethinking 
of one's biography and self-concept in the light of the illness" $[47,48]$. The clinician then explores what the patient reported on the form by asking "What stands out to you on this sheet you filled?" [46,49]. In this way, ICAN facilitates the situation diagnosis by elucidating and sharing insights about the patient's current workload, capacity, and treatment burden to enact treatment plans $[46,49]$. A Web-based implementation tool kit covering workflow integration and conversation training is now freely available [49].

\section{Discussion}

Patients' workloads and capacity need consideration when choosing care strategies. However, this is rarely done when performing shared decision making with patients. We thus propose to use workload and capacity assessments to add insight into the patient context more broadly than disease or decision specific decision aids.

\section{Acknowledgments}

We would like to thank the Amsterdam Public Health research institute for providing TW a travel grant. This travel grant enabled TW to visit the Mayo Clinic (Rochester MN) for 6 weeks in October and November 2017. The foundation of this commentary was created during this period in collaboration with the members of the Knowledge and Evaluation Research Unit of the Mayo Clinic.

\section{Conflicts of Interest}

$\mathrm{KB}$ is the developer of the Instrument for Patient Capacity Assessment (ICAN) discussion aid. ICAN and its implementation tool kit are freely available for download and use at minimallydisruptivemedicine.org/ican. KB received a research grant from the Agency for Healthcare Research and Quality to develop the tool kit, but does not receive any compensation for downloads or use of the aid. KB is the course director of the Mayo Clinic Care that Fits conference where clinicians and researchers are taught in-depth methods for ICAN use in practice and participant course fees are paid directly to the Mayo Clinic. KB does not receive any additional compensation for the course.

The Mayo Clinic Knowledge and Evaluation Research Unit produces and tests shared decision making interventions for patients with chronic conditions. Tools are freely available at http://shareddecisions.mayoclinic.org and no income is generated from their distribution or use. This research did not receive any specific grant from funding agencies in the public, commercial, or not-for-profit sectors. TW's travel grant was assigned based on a different project, which makes the current commentary a side-activity of TW's Mayo Clinic visit. Therefore, the Amsterdam Public Health research institute was not involved in any activities related to the content of this work.

\section{References}

1. Shippee ND, Shah ND, May CR, Mair FS, Montori VM. Cumulative complexity: a functional, patient-centered model of patient complexity can improve research and practice. J Clin Epidemiol 2012 Oct;65(10):1041-1051 [FREE Full text] [doi: 10.1016/i.jclinepi.2012.05.005] [Medline: 22910536]

2. Barnett K, Mercer SW, Norbury M, Watt G, Wyke S, Guthrie B. Epidemiology of multimorbidity and implications for health care, research, and medical education: a cross-sectional study. Lancet 2012 Jul 07;380(9836):37-43 [FREE Full text] [doi: 10.1016/S0140-6736(12)60240-2] [Medline: 22579043]

3. Boyd CM, Darer J, Boult C, Fried LP, Boult L, Wu AW. Clinical practice guidelines and quality of care for older patients with multiple comorbid diseases: implications for pay for performance. JAMA 2005 Aug 10;294(6):716-724. [doi: $\underline{10.1001 / j a m a .294 .6 .716]}$ [Medline: $\underline{16091574]}$

4. Leppin AL, Montori VM, Gionfriddo MR. Minimally disruptive medicine: a pragmatically comprehensive model for delivering care to patients with multiple chronic conditions. Healthcare (Basel) 2015 Jan 29;3(1):50-63 [FREE Full text] [doi: 10.3390/healthcare3010050] [Medline: 27417747]

5. May C, Montori VM, Mair FS. We need minimally disruptive medicine. BMJ 2009 Aug 11;339:b2803. [doi: 10.1136/bmj.b2803] [Medline: 19671932]

6. Van Spall HGC, Toren A, Kiss A, Fowler RA. Eligibility criteria of randomized controlled trials published in high-impact general medical journals: a systematic sampling review. JAMA 2007 Mar 21;297(11):1233-1240. [doi: 10.1001/jama.297.11.1233] [Medline: 17374817]

7. The Commonwealth Fund. 2017 Sep 08. Designing a high-performing health care system for patients with complex needs: ten recommendations for policymakers URL: https://www.commonwealthfund.org/publications/fund-reports/2017/sep/ designing-high-performing-health-care-system-patients-complex

8. Tran V, Barnes C, Montori VM, Falissard B, Ravaud P. Taxonomy of the burden of treatment: a multi-country web-based qualitative study of patients with chronic conditions. BMC Med 2015 May 14;13:115 [FREE Full text] [doi: 10.1186/s12916-015-0356-x] [Medline: 25971838]

9. Eton DT, Ramalho de Oliveira D, Egginton JS, Ridgeway JL, Odell L, May CR, et al. Building a measurement framework of burden of treatment in complex patients with chronic conditions: a qualitative study. Patient Relat Outcome Meas 2012;3:39-49 [FREE Full text] [doi: 10.2147/PROM.S34681] [Medline: 23185121] 
10. Leppin AL, Gionfriddo MR, Kessler M, Brito JP, Mair FS, Gallacher K, et al. Preventing 30-day hospital readmissions: a systematic review and meta-analysis of randomized trials. JAMA Intern Med 2014 Jul;174(7):1095-1107 [FREE Full text] [doi: 10.1001/jamainternmed.2014.1608] [Medline: 24820131]

11. Weiner SJ, Schwartz A, Weaver F, Goldberg J, Yudkowsky R, Sharma G, et al. Contextual errors and failures in individualizing patient care: a multicenter study. Ann Intern Med 2010 Jul 20;153(2):69-75. [doi: 10.7326/0003-4819-153-2-201007200-00002] [Medline: 20643988]

12. Frosch DL, Kaplan RM. Shared decision making in clinical medicine: past research and future directions. Am J Prev Med 1999 Nov;17(4):285-294. [doi: 10.1016/s0749-3797(99)00097-5] [Medline: 10606197]

13. Barry MJ. Involving patients in medical decisions: how can physicians do better? JAMA 1999;282(24):2356-2357. [doi: 10.1001/jama.282.24.2356] [Medline: 10612326]

14. Sepucha KR, Fowler FJ, Mulley AG. Policy support for patient-centered care: the need for measurable improvements in decision quality. Health Aff (Millwood) 2004;Suppl Variation:VAR54-VAR62. [doi: 10.1377/hlthaff.var.54] [Medline: 15471772]

15. Hargraves I, LeBlanc A, Shah ND, Montori VM. Shared decision making: the need For patient-clinician conversation, not just information. Health Aff (Millwood) 2016 Apr;35(4):627-629. [doi: 10.1377/hlthaff.2015.1354] [Medline: 27044962]

16. Shay LA, Lafata JE. Where is the evidence? a systematic review of shared decision making and patient outcomes. Med Decis Making 2015 Jan;35(1):114-131 [FREE Full text] [doi: 10.1177/0272989X14551638] [Medline: 25351843]

17. Clayman ML, Bylund CL, Chewning B, Makoul G. The impact of patient participation in health decisions within medical encounters: a systematic review. Med Decis Making 2016 May;36(4):427-452. [doi: 10.1177/0272989X15613530] [Medline: $\underline{26585293}]$

18. Kunneman M, Montori VM, Castaneda-Guarderas A, Hess EP. What is shared decision making? (and what it is not). Acad Emerg Med 2016 Dec;23(12):1320-1324 [FREE Full text] [doi: 10.1111/acem.13065] [Medline: 27770514]

19. Sullivan MD, Leigh J, Gaster B. Brief report: training internists in shared decision making about chronic opioid treatment for noncancer pain. J Gen Intern Med 2006 Apr;21(4):360-362 [FREE Full text] [doi: 10.1111/j.1525-1497.2006.00352.x] [Medline: 16686813 ]

20. Elwyn G, Edwards A, Hood K, Robling M, Atwell C, Russell I, Study Steering Group. Achieving involvement: process outcomes from a cluster randomized trial of shared decision making skill development and use of risk communication aids in general practice. Fam Pract 2004 Aug;21(4):337-346. [doi: 10.1093/fampra/cmh401] [Medline: 15249520]

21. Schneider CE. The Practice Of Autonomy: Patients, Doctors, And Medical Decisions. New York: Oxford University Press; 1998.

22. Emanuel EJ, Emanuel LL. Four models of the physician-patient relationship. JAMA 1992;267(16):2221-2226. [Medline: 1556799]

23. Eddy DM. Clinical decision making: from theory to practice. Anatomy of a decision. JAMA 1990 Jan 19;263(3):441-443. [doi: 10.1001/jama.263.3.441] [Medline: 2294311]

24. Montori VM, Gafni A, Charles C. A shared treatment decision-making approach between patients with chronic conditions and their clinicians: the case of diabetes. Health Expect 2006 Mar;9(1):25-36 [FREE Full text] [doi: 10.1111/j.1369-7625.2006.00359.x] [Medline: 16436159]

25. Britten N, Stevenson FA, Barry CA, Barber N, Bradley CP. Misunderstandings in prescribing decisions in general practice: qualitative study. BMJ 2000 Feb 19;320(7233):484-488 [FRE Full text] [doi: 10.1136/bmj.320.7233.484] [Medline: 10678863]

26. Wennberg JE. Tracking Medicine: A Researcher's Quest To Understand Health Care. New York: Oxford University Press; 2010.

27. Elwyn G, Edwards A, Thompson R. Shared Decision Making In Health Care: Achieving Evidence-based Patient Choice. New York: Oxford University Press; 2016.

28. Griffin SJ, Kinmonth A, Veltman MWM, Gillard S, Grant J, Stewart M. Effect on health-related outcomes of interventions to alter the interaction between patients and practitioners: a systematic review of trials. Ann Fam Med 2004;2(6):595-608 [FREE Full text] [doi: 10.1370/afm.142] [Medline: 15576546]

29. Hoffmann TC, Montori VM, Del Mar C. The connection between evidence-based medicine and shared decision making. JAMA 2014 Oct 01;312(13):1295-1296. [doi: 10.1001/jama.2014.10186] [Medline: 25268434]

30. Lin GA, Fagerlin A. Shared decision making: state of the science. Circ Cardiovasc Qual Outcomes 2014 Mar;7(2):328-334. [doi: 10.1161/CIRCOUTCOMES.113.000322] [Medline: 24496297]

31. Stiggelbout AM, Van der Weijden T, De Wit MPT, Frosch D, Légaré F, Montori VM, et al. Shared decision making: really putting patients at the centre of healthcare. BMJ 2012 Jan 27;344:e256. [doi: 10.1136/bmj.e256] [Medline: 22286508]

32. President's Commission for the Study of Ethical Problems in Medicine and Biomedical and Behavioral Research. Washington, DC: US Government Printing Office; 1982 Oct. Making health care decisions URL: https://repository.library.georgetown.edu/ bitstream/handle/10822/559354/making health care decisions.pdf

33. Charles C, Gafni A, Whelan T. Shared decision-making in the medical encounter: what does it mean? (or it takes at least two to tango). Soc Sci Med 1997 Mar;44(5):681-692. [doi: 10.1016/s0277-9536(96)00221-3] [Medline: 9032835] 
34. Charles C, Gafni A, Whelan T. Decision-making in the physician-patient encounter: revisiting the shared treatment decision-making model. Soc Sci Med 1999 Sep;49(5):651-661. [doi: 10.1016/s0277-9536(99)00145-8] [Medline: 10452420]

35. Makoul G, Clayman ML. An integrative model of shared decision making in medical encounters. Patient Educ Couns 2006 Mar;60(3):301-312. [doi: 10.1016/j.pec.2005.06.010] [Medline: 16051459]

36. Coulter A. Partnerships with patients: the pros and cons of shared clinical decision-making. J Health Serv Res Policy 1997 Apr;2(2):112-121. [doi: 10.1177/135581969700200209] [Medline: 10180362]

37. Towle A, Godolphin W. Framework for teaching and learning informed shared decision making. BMJ 1999 Sep 18;319(7212):766-771 [FREE Full text] [doi: 10.1136/bmj.319.7212.766] [Medline: 10488010]

38. Elwyn G, Frosch D, Thomson R, Joseph-Williams N, Lloyd A, Kinnersley P, et al. Shared decision making: a model for clinical practice. J Gen Intern Med 2012 Oct;27(10):1361-1367 [FREE Full text] [doi: 10.1007/s11606-012-2077-6] [Medline: 22618581]

39. Légaré F, Stacey D, Pouliot S, Gauvin F, Desroches S, Kryworuchko J, et al. Interprofessionalism and shared decision-making in primary care: a stepwise approach towards a new model. J Interprof Care 2011 Jan;25(1):18-25 [FREE Full text] [doi: 10.3109/13561820.2010.490502] [Medline: 20795835]

40. Wieringa TH, Kunneman M, Rodriguez-Gutierrez R, Montori VM, de Wit M, Smets EMA, et al. A systematic review of decision aids that facilitate elements of shared decision-making in chronic illnesses: a review protocol. Syst Rev 2017 Aug 07;6(1):155 [FREE Full text] [doi: 10.1186/s13643-017-0557-9] [Medline: 28784186]

41. Wieringa TH, Rodriguez-Gutierrez R, Spencer-Bonilla G, de Wit M, Ponce OJ, Sanchez-Herrera MF, et al. Decision aids that facilitate elements of shared decision making in chronic illnesses: a systematic review. Syst Rev 2019 May 20;8(1):121 [FREE Full text] [doi: 10.1186/s13643-019-1034-4] [Medline: 31109357]

42. O'Connor AM, Llewellyn-Thomas HA, Flood AB. Modifying unwarranted variations in health care: shared decision making using patient decision aids. Health Aff (Millwood) 2004;Suppl Variation:VAR63-VAR72. [doi: 10.1377/hlthaff.var.63] [Medline: $\underline{15471770]}$

43. Llewellyn-Thomas HA. Patients' health-care decision making: a framework for descriptive and experimental investigations. Med Decis Making 1995;15(2):101-106. [doi: 10.1177/0272989X9501500201] [Medline: 7783569]

44. Stacey D, Légaré F, Lewis K, Barry MJ, Bennett CL, Eden KB, et al. Decision aids for people facing health treatment or screening decisions. Cochrane Database Syst Rev 2017 Apr 12;4:CD001431 [FREE Full text] [doi: 10.1002/14651858.CD001431.pub5] [Medline: 28402085]

45. Joseph-Williams N, Newcombe R, Politi M, Durand M, Sivell S, Stacey D, et al. Toward minimum standards for certifying patient decision aids: a modified delphi consensus process. Med Decis Making 2014 Aug;34(6):699-710. [doi: 10.1177/0272989X13501721] [Medline: 23963501]

46. Boehmer KR, Hargraves IG, Allen SV, Matthews MR, Maher C, Montori VM. Meaningful conversations in living with and treating chronic conditions: development of the ICAN discussion aid. BMC Health Serv Res 2016 Sep 23;16(1):514 [FREE Full text] [doi: 10.1186/s12913-016-1742-6] [Medline: 27663302]

47. Bury M. Chronic illness as biographical disruption. Sociol Health Illn 1982 Jul;4(2):167-182 [FREE Full text] [doi: 10.1111/1467-9566.ep11339939] [Medline: 10260456]

48. Pollard R, Saleem H. Reproductive identities following an HIV diagnosis: strategies in the face of biographical disruption. Cult Health Sex 2019 Apr 23:1-13. [doi: 10.1080/13691058.2019.1603399] [Medline: 31012809]

49. Mayo Clinic's Knowledge and Evaluation Research (KER) Unit. Minimally Disruptive Medicine. My life my health care URL: https://minimallydisruptivemedicine.org/ican [accessed 2020-01-31]

\section{Abbreviations}

ICAN: Instrument for Patient Capacity Assessment

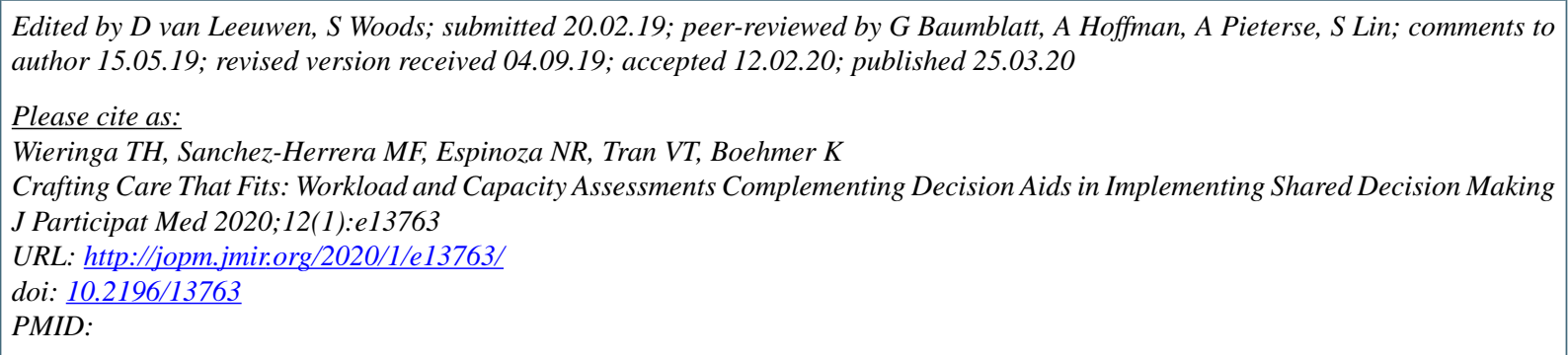


(C)Thomas H Wieringa, Manuel F Sanchez-Herrera, Nataly R Espinoza, Viet-Thi Tran, Kasey Boehmer. Originally published in Journal of Participatory Medicine (http://jopm.jmir.org), 25.03.2020. This is an open-access article distributed under the terms of the Creative Commons Attribution License (https://creativecommons.org/licenses/by/4.0/), which permits unrestricted use, distribution, and reproduction in any medium, provided the original work, first published in Journal of Participatory Medicine, is properly cited. The complete bibliographic information, a link to the original publication on http://jopm.jmir.org, as well as this copyright and license information must be included. 